\title{
Youth Subcultures of the USSR in the 1950-1980s
}

\author{
Stanislav Gennadyevich Davydov \\ Leo Tolstoy Institute of Language and Cultures \\ Moscow, Russia \\ E-mail: a105trk@yandex.ru
}

\begin{abstract}
The present article deals with subcultures and amateur cultural activities of the Soviet youth. It attempts to substantiate the important role those socio-cultural youth innovations played in the USSR. Subcultural entities provided the patterns of cultural behavior, further developed into models of conduct for the younger generation of Soviet citizens. Specific examples illustrate that there are two lines of the subcultural movement: subcultures developed under the Western influence and those of domestic origin.
\end{abstract}

It is also stated that despite the counteractions taken by the authorities (until the late 1980s), not only did subcultures not disappear, but they even expanded their influence on the Soviet youth.

Keywords-youth subcultures; rock music; "stilyagi"; hippies; local and territorial youth subcultures; counterculture; criminal (thieves') subculture

\section{INTRODUCTION}

Being a part of the common cultural space, the youth subcultures of the Soviet Union are of particular interest. Studying them provides a more comprehensive overview of the socio-cultural life in the USSR, allows to see the whole range of hobbies and leisure activities of the Soviet youth, as well as to understand their inner world.

In Soviet times, until the mid-1980s, subcultures were understood as a feature of the capitalist culture and were subject to criticism and condemnation. As for the informal movement of the Soviet youth itself, for a long time, its phenomenon had not been studied and objectively evaluated by official structures and social scientists. In the late 1980s, these attitudes were changed, the right of youth subcultures to exist was recognized, and the problem of informal people became topical. In 1990-2000s, numerous works on the informal activities of the Soviet youth were published, a variety of theses studying the phenomenon of youth subcultures from the standpoint of history, sociology, and culture, were completed. ${ }^{1}$ Nevertheless, it cannot be said that the topic of the Soviet youth subcultures has been covered

Mamukina G I. Informal urban groups as objects of social management. Dissertation for a Candidate Degree in Social Sciences Moscow, 2004. Ivashnikov K.V. Informal amateur associations in the USSR: historical and cultural aspect. 1985-1991. Dissertation for a Candidate Degree in History. - Moscow, 2008. Klyavina I. I. Author (bard) song as a phenomenon of youth subculture in Russia in the 1950-1960s. Dissertation for a Candidate Degree in Cultural Science - Kemerovo, 2002, etc. and dealt with fully. Local subcultures, some aspects of the already known subcultures, the authorities' activity towards them and the reaction of the Soviet public to youth innovations are still to be studied.

\section{Youth Subcultures OF Foreign ORIGIN}

The "stilyagi" subculture is traditionally considered to be the first post-war subculture. It was based on the enthusiasm for the officially disapproved jazz music ("stilyagi" communicated with jazz people and played music themselves), modern foreign dances and western fashion, to the extent possible at that time. Under the then existing regime, jazz became a kind of an opposing worldview, and its spreading among young people was synonymous with the dissemination of freethinking.

The period of the "classical" "stilyagi" movement, significantly affected by "Teds" and "Beatniks" subcultures, fell on the late 1950s - early 1960s. Both in the capital and in different cities around the country, the stylish youth appeared in the main pedestrianized streets and manifested themselves by means of clothes, slang and manners, often giving the ordinary Soviet citizens a cultural shock. First, "stilyagi" subculture was characteristic of a narrow circle of the youth, but soon enough, it developed into several groups, each having its own specific features.

In a short while, jazz was no longer considered by the authorities as a dangerous phenomenon, inflicting ideological harm to the Soviet worldview. Jazz had already become a part of the official culture, so its gradual institutionalization, as well as changes of the Western youth's hobbies, led to the decline of the "stilyagi" subculture. New subcultural entities were replacing it, for instance, hippies that appeared in the Soviet Union in the late 1960s. The exact time of this subculture emergence is rather difficult to identify, but already in winter, 1970, young longhaired people gathered on the streets of Moscow to sing: "Let there be no wars and revolutions! Love! Love! Love!" [1]. In the early 1970s, growing hippie communities with dozens of participants already existed in Moscow, Leningrad and the Baltic states [2]. It should be emphasized that the "Soviet hippies" did not simply copy the hippies of the West. Borrowed from abroad, the new youth fashion and worldview was organically supplemented with the domestic idea of "pochvennichestvo" (nativism, concept of the soil).

By the mid-1970s, hippies segregated into the "old" generation, espousing the rejection of social activity; the 
"System", bringing together young people whose primary goal was self-expression and spiritual liberation; and "pacifists", rejecting any political systems. Some prominent figures of the pacifist movement of the late 1970-1980s came from the ranks of hippies. The changing sociocultural space and domestic political situation of the 1980s facilitated certain revival of hippism, which, however, resulted in its decline at the end of the decade.

In terms of music, the hippie subculture was based on rock, which replaced jazz. The Soviet youth was overwhelmed by Beatlemania and big beat. Rock completely satisfied the aesthetic requirements of the youth of the 19601970s, and due to its international character and democratic nature, was a phenomenal success among young people.

In fact, practically the whole Soviet rock culture was created by amateur musicians: more common than not, rock did not demand the same level of instrument mastery, as jazz. Besides, in Soviet rock, especially when most of it was in the Russian language, the lyrics were of greater importance than music. The first Soviet rock bands were established in the mid-1960s in Moscow and Leningrad, and before long, appeared all around the country.

The "tape culture" - the fashion to listen to tape recordings - substantially contributed to the proliferation of rock music. Within the period of 1964-1966, about 900 thousand tape recorders were produced in the country [3]. The technological revolution provided ample opportunities for the uncontrolled access to music through copying records brought from abroad. Tape recordings, original and copied phonograph records of foreign singers, the information on music from mass media, and communicating with peers served as motives for the youth, particularly adolescents, to join together and form informal groups of specific interests.

In the USSR, listening to rock, not to mention playing it, meant taking one's independent stand, often non-complying with regulatory requirements. A.S. Bashlachyov, the renowned rock musician, once explained it in his interview: "you should justify every song you sing and live its lyrics. So, if you sing about certain attitude to society, have this attitude and live accordingly." [4].

In spite of the countermeasures taken by the authorities, rock-culture as a means of communication and selfexpression was developing and becoming increasingly attractive for the youth. By 1980-1983, the rock movement developed into a popular Soviet Union subculture, having its own symbols, values, slang, its own press (underground press - rock magazines), and a network of underground rehearsal and recording facilities. Gradually, the three centres of the Soviet rock culture were formed: Moscow, Leningrad and Ural, representing the three schools, each characterized with its own specific creative features. However, what they all shared was the idea of lyrics being much more important in Soviet rock than music.

In the late 1980s, the rock movement lost its countercultural status and turned into a customary, accepted pattern of behaviour for young people.
A distinguishing feature of the described period was the reduced time between the emergence of a youth subculture in the Western world and the appearance of its adherents in the USSR. For instance, the representatives of the USSR punk subculture came on the scene almost simultaneously with the punk subculture of the West. Such bands as "Sex Pistols" and "Clash" quickly became their idols. Punk parties and punk-music groups were particularly widespread in Moscow, Leningrad and Siberia. Facilitated by perestroika and the connected changes in the society, the second half of the 1980s was marked by the explosive growth in the number of punks and bands playing punk rock.

Amateur youth innovations were expanding rapidly around the country. Rockers, mods, "breakers" (breakdance subculture), and other youth subcultures attracted a great many informal people, who were avoiding official control and discounting the possibility of socialization through established institutions. In the early 1980 s, about $45 \%$ of the youth in large cities identified themselves with informal groups, while by mid-decade, young people considering themselves informal already accounted for $60 \%$ [5].

The heavy metal subculture, one of the most numerous Soviet youth subcultures to be described as an "interest group", assumed particular significance in the late 1980s. The popularity of heavy metal was at its height at a critical point of the country's history - the second half of the 1980s. The 1989 Moscow Rock Festival of Peace in Luzhniki, with Mötley Crüe, Cinderella, Ozzy Osbourne and Scorpions performing, illustrated the large-scale involvement of people in this subculture: the festival attracted approximately 200,000 heavy metal fans.

"Skinheads", a subculture that appeared in the USSR in the late 1980s, were also enthusiastic about heavy metal and were distinguished by highly intensive antisocial activities. Their typical aggressiveness and the inclination to deviation regularly led to conflicts, fully manifested in the 1990s.

\section{YOUTH SUBCULTURES: USSR ORIGIN}

In should be noted that amateur youth innovations of the USSR included not only pro-Western subcultures; there also existed subcultural entities not influenced from the outside.

The criminal (thieves') subculture was deeply ingrained in the youth environment, and the crime-prone youth acted as transmitters and bearers of this subculture, its specific trends, and code of conduct. Ordinary young people were affected and even charmed with the romantic appeal of thieves' folklore, prison morals and criminal slang [6]. The influence of the criminal subculture was truly ubiquitous and was easily discernible in various young people's amateur activities. For example, so-called radio-hooliganism, a hobby of secondary school students, university students and the working youth, who organized illegal radiobroadcasts [7]. The so-called "hooligan songs" constituted a significant part of such radio shows. The criminal countercultural intonation of those songs appealed to Soviet people's tastes, therefore, a considerable part of the uncensored, underground songs circulating in the society was devoted to prisons and the romantic appeal of thieves' lives. 
Criminal, countercultural intonation was transparent in author song (bard music) as well, although it was not its leitmotiv. The interest in composing "guitar poetry" was a massive and significant subcultural trend, egalitarian in nature. University students, working youth, school students almost immediately accepted author song as a means of selfexpression. Due to uneasy relationship with official authorities, the movement mostly developed through "tape culture", amateur song clubs (KSP), and youth events.

In the 1970-1980s, many young people belonged to street groups. Their social core was represented by the marginalized urban youth, the majority of which were rural migrants having difficulty adapting to new living conditions. Not infrequently, youth street groups were influenced and strictly controlled by the people with considerable criminal experience. It ensured regular reproduction of criminal values and standards in the youth environment. Meanwhile, "age characteristics of adolescents and the youth were taken into account to the maximum extent". [8]

The "motalki" youth groups became widely known in Kazan, and by 1986, they involved about 8 thousand adolescents aged 14 to 18 [9]. The members of these groups had their own "dress code": quilted jackets, track pants, boots known as "proshchay molodost", and hats with bobs. Among other local and territorial youth subcultures of the Soviet Union of the 1970-1980s were the "chistilshchiki", "remontniki", "dvorniki", "furagi" and others, all uniting lower class young people. They released the accumulated negative energy in fierce opposition to "strangers," which often meant members of westernized subcultures.

One of subcultures to move beyond the narrow territorial boundaries and become widely known in the late 1980s, was the "lyubera". Initially, the name referred to the specific location of the youth group - the city of Lyubertsy near Moscow. Later, it was used to name all adherents of this subculture around the country. The phenomenon of the "lyubera" illustrates a particular case of aggressive, hooligan subcultures, affected by socio-economic and political conditions of that time and the associated shifts in public consciousness.

Another significant subcultural entity of the 1980s, spreading all over the Soviet Union, was the sports fans movement, generally represented by 12-17-year-old schoolchildren and students of vocational training schools. Fans were really organized and had well-established links with like-minded people in different cities around the country. This enabled them to hold mass activities to support their favourite sports teams, sometimes, not without disruptive behaviour.

For many young people, the football subculture was a lifestyle, a social union, where they could be a part, understand their role and feel secure.

\section{AUTHORITIES AND Youth SUbCULTURES}

Until the late 1980s, the authorities and most of Soviet society considered youth subcultures (primarily those of Western origin) to be undesirable and even harmful. The authorities thought informal socialization to be dangerous, as it interfered with delivering socially organized ideological information. To encounter those manifestations, the media, the Komsomol community, and law enforcement authorities were actively mobilized. However, when exercising the "communist vigilance", the law and rights of Soviet citizens were often violated.

The common methods of rehabilitation of delinquents included the following: carrying out raids, administrative authorities control, inducting into military service and compulsory employment in order to re-educate in the work environment. Sometimes, even more desperate measures had to be taken, like sending into psychiatric hospitals and psycho-neurologic dispensaries.

Unfortunately, the taken measures failed to provide longterm results, since the reasons for the emergence of youth subcultures were more profound than the Soviet authorities thought them to be. They expected Soviet people to be equal and identical and did not compromise the principle of the impeccability of a "monostylistic" Soviet culture.

Nevertheless, even having failed to confront amateur youth innovations, the authorities neither reviewed their positions, nor realized the need to make the process of youth socialization more flexible. However, it is difficult to blame them for it, since such radical steps required serious changes to the system of youth work.

The societal response to subcultures remained negative and each new phenomenon was met with hostility. However, the large-scale involvement of people in subcultures and their appeal to the broad youth population led to some changes to the practice of counteracting them. For example, in case of rock culture, beside standard measures, there also was an option of establishing pseudo-rock vocalinstrumental ensembles (VIA), aimed at imposing formal requirements on amateur youth activity and making it devoid of its "rock" meaning. Centred around the same instruments and the characteristics typical of rock bands, the music of VIAs imitated and resembled rock, but was deprived of the protest spirit and corresponding values. Young people could observe the absence of counterculture, therefore, all attempts to have rock under control were doomed to failure.

Until 1982, some rare attempts were made to bring the rock movement under control, but they were not crowned with success. At the Vth Plenum of the Komsomol Central Committee in 1982, dedicated to ideological and moral education of young people, it was emphasized that music was "the arena of the uncompromising battle for hearts and minds of the youth" [10]. Nevertheless, the attempt to achieve success in this battle suffered a setback. In 1985, in Oryol region, when questioned about the preference as to which amateur vocal-instrumental ensembles and rock groups were the best, most positively acclaimed were those, which Komsomol workers defined as "inflicting considerable ideological harm" [11].

In the late 1980s, when entry barriers for innovations were lowered, many objectionable prohibitions were abolished, changes were introduced to the system of youth 
Since late 1980s, young people had more opportunities to satisfy their needs. Gradually, subcultures embraced more and more people and were practically a common occurrence, rather than something exotic. However, there was also a negative point - increased antisocial activities in some subcultures.

\section{REFERENCES}

[1] Moscow Central archive of social movements. F. 635, op. 17, d. 156, 1. 46.

[2] Russian State Archive of Contemporary History. F. 5, op.64, d.15, 1. 65.

[3] Russian State Archive of Contemporary History. F. 5, op. 36, d. 157, 1. 57.

[4] Interview with A. Bashlachyov // Kontrkultura. 1991. No. 3. p. 39.

[5] Informal youth groups. Kiev. 1988. p. 12.

[6] Russian State Archive of Socio-Political History. F. M-1. op. 32, d. 639, 1. 35.

To conclude, the youth subcultures of the USSR in the 1950-1980s represented a significant part of the amateur youth activities. They satisfied the needs of the youth, which could not be satisfied through official structures.

Large cities became the centres of amateur cultural activity of the Soviet Union youth; young people, particularly high school students and university students, represented the social core of subcultures.

The Western youth subcultures served as referential patterns for many cultural innovations of the Soviet youth. First and foremost, they adopted the appearance and outer features: symbols, slang, clothes, etc. However, even doing so, they did not simply copy them: Western subcultures were analyzed by young people and tailored to their needs.

The history of the development of the Soviet Union youth subcultures reveals tendencies towards expanding, increasing the number of participants and adopting Western models.

Youth subcultures were based on popular musical trends, such as jazz, author song (bard music), and rock music. Being key musical preferences for the youth, these music genres significantly contributed to the creation of the informal style in general.

Not all youth subcultures were influenced by foreign patterns. For instance, local and territorial subcultures developed simultaneously but independently. They united mainly the lower class of the urban youth, and to a greater or lesser extent were influenced by the criminal environment, its values and norms. Some mass subcultures were also exposed to their influence, but to a different degree.

Up to the late 1980s, the authorities rigorously considered all youth subcultures to be an undesirable phenomenon in the youth environment and introduced prohibitive policies and measures against them. Those actions ended up ineffective in the long-term perspective and led to various complications in communication with the young generation.
[7] Russian State Archive of Contemporary History. F. 1, op. 5, d. 974, 1. 83.

[8] V.F. Pirozhkov. Criminal subculture of adolescent students and young men. Dissertation abstract. Moscow. 1992.

[9] Criminologists on informal youth groups. Moscow. 1990, p. 166

[10] Russian State Archive of Socio-Political History. F. M-1, op. 41, d. 756, 1. 192

[11] Russian State Archive of Contemporary History. F. 1, op. 90, d. 243, 1. 39 